\title{
Research Streams in Cluster Upgrading. A Literature Review
}

\section{Marta Gancarczyk $^{1}$, Joanna Bohatkiewicz ${ }^{2}$}

\begin{abstract}
This paper aims to identify and systemize the research streams in regional cluster upgrading. Cluster upgrading belongs to broader research in the dynamics of ind ustrial agglomerations, currently, the major topic in studies on clusters. Within this literature, the upgrading concept differentiates by the focus on structural change in response to the insertion of regional clusters into global value chains (GVCS). Based on the narrative literature review, we identify and discuss two major research streams and classify them as the positive and the normative. Moreover, we elaborate a framework for studying the antecedents of cluster upgrading to conclude with research questions that may serve further systematic reviews and empirical investigations. This paper provides two contributions to the cluster dynamics literature with a focus on the upgrading of industrial agglomerations. First, it offers a comprehensive approach to the cluster upgrading theory by integrating the fragmented research in this area. Second, it proposes a theoretical framework to set up further research directions.

Keywords: cluster upgrading, global value chains, cluster evolution, cluster life cycles, capabilities, governance
\end{abstract}

\section{INTRODUCTION}

Cluster upgrading belongs to rapidly developing research in the dynamics of industrial agglomerations that represents a major issue both for academia and policy-makers. Its importance lies in the prospective approach, relevant for the adaptive and proactive planning of regional development, while the majority of extant research on clusters is focused on their on-going or past competitive advantage. Within the cluster dynamics research, the upgrading concept focuses on the improvement of regional clusters'

1 Marta Gancarczyk, Dr. Hab., Associate Professor, Department of Globalization and Economic Integration, Institute of Economics, Finance and Management, Faculty of Management and Social Communication, Jagiellonian University, Prof. Stanislaw Lojasiewicz 4, 30-415 Krakow, Poland, e-mail: marta.gancarczyk@uj.edu.pl

2 Joanna Bohatkiewicz, Ph.D. Student and Lecturer at the Faculty of Management and Social Communication, Jagiellonian University Prof. Stanislaw Lojasiewicz 4, 30-415 Krakow, Poland, e-mail: joanna.bohatkiewicz@gmail.com 
positions in global value chains (GVCs), i.e., it acknowledges the insertion of regional agglomerations into global exchange (Humphrey \& Schmitz, 2004a; Gereffi, Humphrey \& Sturgeon 2005; Saxenian, 2007). This concept is also closely linked to the current interest in learning and knowledge transfer through international cooperation that prevents regional lock-in (Lam, 2007; Lorentzen, 2008; De Propris et al., 2008; Malecki, 2010; Wall \& Van der Knaap, 2011; Gancarczyk, 2015a; Geodecki \& Grodzicki, 2015).

The concept of upgrading is explored both at enterprise and industry levels to explain the advancement in relative competitive position due to cross-border contracts (Lager, 2000; Schmitz, 2006; Aspers, 2010; Ivarsson \& Alvstam, 2011; Simms \& Trott, 2014). This advancement of position reflects in higher value adding activities accomplished through capability development in the area of products, processes, functions, and new value chains (Humphrey \& Schmitz, 2002; Gereffi et al., 2005; Kaplinsky \& Morris, 2001; Aspers, 2010). Therefore, both research and practice focus on how to maintain and advance the positions of clusters in global value chains through developing higher value adding activities.

As with other development processes of an evolutionary and multidimensional nature, upgrading requires the investigation of complex and interrelated antecedents with regard to firm, industry, and institutional setup in the spatial context (Fornahl \& Hassink, 2017; Trippl et al., 2015). The theoretical background and empirical studies are vitally developing in this area, with a call for knowledge accumulation and setting up a comprehensive conceptual framework to study the antecedents (factors, drivers, determinants) of cluster upgrading. Therefore, this paper aims to identify and systemize the research streams in cluster upgrading with the adoption of a narrative literature review as a research method.

In the following sections of the paper, we identify and discuss two major research streams proposed as the positive and the normative. The positive stream, including the GVC governance, capability and evolutionary approaches, aims to explain the antecedents of upgrading as objective and non-intentional antecedents of cluster dynamics. The normative stream proposes proactive, intentional behaviors of cluster lead firms and public policy interventions to stimulate upgrading processes. Moreover, we propose a framework for studying the antecedents of cluster upgrading stemming from these two perspectives. Finally, research questions have been formulated that may serve further systematic reviews and empirical studies. The concluding section synthesizes the results in relation to extant studies and sets directions for future research.

The paper provides two contributions to the cluster dynamics literature with a focus on the upgrading of industrial agglomerations. First, it provides 
a comprehensive approach to cluster upgrading by integrating the fragmented research in this area. Second, it proposes a theoretical framework to set up new research directions.

\section{RESEARCH METHOD}

The major research method was a narrative literature review. A narrative review differentiates by qualitative, comprehensive and up-to-date approaches to a selected topic, based on the printed and electronic books and journal articles (Kirkevold, 1997; Collins \& Fauser, 2005). It also features a subjective component when determining the studies for review and discussing results. However, the selection procedure and choices need to be explained (Green, Johnson, \& Adams, 2006).

Nevertheless, narrative reviews are valuable for the synthesis of the development of a phenomenon under study, pointing to the most up-to-date achievements in the field, and often for critical lenses, attempting to set out new views on the topic (Jones, 2004; Green et al., 2006). This comprehensive, qualitative, and critical analysis of extant literature enables one to comprehend the diversities and pluralities of a given phenomenon (Jones, 2004). Such an approach is justified by the breadth and often initial development stages of the field under study. As an outcome, narrative reviews may be expected to identify specific research questions for further investigations in the form of empirical tests or systematic reviews.

In contrast, the systematic literature review starts with a specific research question(s). Moreover, it adopts relevant databases to identify the large stock of studies with the use of key words, and according to specific criteria of inclusion and exclusion (Thomas \& Harden, 2008). By this rigorous attitude, systematic reviews can employ quantitative statistical methods to process the findings from empirical evidence (Collins \& Fauser, 2005).

Since our research aims to identify and systemize a broad topic of research streams in cluster upgrading, a growing but still new phenomenon, the narrative review is an appropriate method. First systematic reviews in this area address one established theoretical approach of GVCs with the specific questions, such as learning channels that condition upgrading (c.f. De Marchi, Giuliani, \& Rabellotti, 2017). Our paper intends to capture a wider horizon of theoretical lenses to end with research questions that may guide further systematic literature reviews and empirical investigations.

The foundations of our broad perspective was an interdisciplinary literature search that included research papers, monographs, and research reports in development and political economics, economic geography, as 
well as entrepreneurship and regional development. We included not only the literature that adopts a predominant theoretical approach of the GVC governance, but also the studies in cluster dynamics with such theoretical lenses as capability approach, life cycles, and the evolution of industrial spatial forms. We reviewed both theoretical and empirical studies to describe the theories of upgrading, including their development phases. Following this, we have established the major research approaches, their propositions about upgrading drivers, and logical interdependencies among these approaches. In the next step, we have categorized the approaches as belonging to normative or positive research streams that study cluster dynamics. The research procedure concludes with a framework for studying the antecedents of cluster upgrading and questions for further investigations.

\section{LITERATURE REVIEW}

\section{The essence of cluster upgrading in the GVC literature}

Clusters (industrial agglomerations, industrial districts, and industrial production systems) differentiate by spatial industrial concentration that implies regional specialization, and by network relationships conducive for knowledge and innovation development (Porter, 1990; 1998; Vanhaverbeke, 2001; European Commission, 2002; Brusco, 1982; Pyke, Sengenberger, 1992; Markusen, 1996; Saxenian, 2000; Asheim \& Isaksen, 2003, pp. 3640; Gancarczyk, 2015). The traditional view on industrial agglomerations presents them as self-sufficient production systems comprising the majority of functions in value chains of their dominant industries (Bellandi, 2001; Piore, Sabel, 1984; Krugman, 1991; Porter, 1998). However, globalization and spatial fragmentation of production and innovation turned clusters into chain links within cross-border value chains (Gereffi et al., 2005; McKinnon, 2012; Humphrey \& Schmitz, 2002; Sturgeon, 2003; Pietrobelli \& Rabellotti, 2011; MacKinnon, 2012; Aslesen \& Harirchi, 2015; Sturgeon, Van Biesenbroeck, \& Gerefii, 2008). Clusters became more specialized through offshore outsourcing and relocation activities (Aslesen \& Harirchi, 2015; Gancarczyk \& Gancarczyk, 2018). One of the most critical issues in this specialization concerns either higher or lower value-adding functions in the global production chains, since this specialization translates into hierarchy and power relations among different regions and unequal division of economic returns. The major research and practical problem arise, how clusters can maintain and advance (upgrade) their positions in global value chains through developing higher value-adding activities. 
Upgrading is understood as the advancement into higher value adding activities through the development of capabilities in the area of products, processes, functions and new value chains (Gereffi 1996; Humphrey \& Schmitz, 2002; Humphrey \& Schmitz, 2004a; Humphrey \& Schmitz, 2004b). In relation to clusters, upgrading is the improvement of the relative competitive position of clusters' dominant industries in global value chains. The opposite process is downgrading, going down the value chain to lower value activities (Simms \& Trott, 2014; Lager, 2000).

The phenomenon of upgrading is investigated in the global value chain (GVC) approach, focused on the positive explanation of how governance affects the roles, power relationships, and competitive positions of contracting partners (Gereffi, 1996; Humphrey \& Schmitz, 2002; Humphrey \& Schmitz, 2004a; Humphrey \& Schmitz 2004b; Gereffi et al., 2005; Sturgeon et al., 2008). Governance means modes or structures of regulating economic activities that include the market, the firm (hierarchy), and hybrids integrating markets and hierarchies (Williamson, 1991). The nature of governance in the GVC concept is micro-economic since it seeks firm-level drivers of upgrading clusters and regions.

The GVC approach assumes that inter-firm governance affects not only the current competitive position but also the future one, in terms of upgrading in value chains (Kaplinsky \& Morris 2001; Humphrey \& Schmitz, 2002; Gereffi et al. 2005; Pietrobelli \& Rabellotti, 2011). Five types of governance modes are considered, namely, markets, hierarchy (the firm), and three types of network structures. The market mode assumes spot and short-term transactions that do not engage any in-depth interaction, while the firm represents internal transaction where the external knowledge transfer is not considered. Therefore, upgrading can occur in network relationships, since they involve relatively firm, repetitive collaboration that implies a transfer of knowledge between partners. Nevertheless, each of the governances offers different prospects for supplier upgrading. Captive networks feature hierarchical and top-down relationships that provide limited opportunities for learning and development and may pose a threat of lock-in for suppliers (Gereffi et al., 2005). Suppliers predominantly focus on lower-value adding and standardized activities, following strict terms of quality and supplies (Rugraf, 2010; Pavlínek, 2012; Gancarczyk \& Gancarczyk, 2013). In modular networks and relational networks, suppliers can benefit from upgrading, since the cooperation is less hierarchical and more balanced, thus encouraging more in-depth interaction (Humphrey \& Schmitz, 2004b; Winter, 2010; Gereffi et al., 2005).

Governance modes are largely determined by the more powerful party in international exchange, predominantly, customers to suppliers from 
less developed countries. However, they are not purely subjective and subordinated to the discretion of individual buyers, since they also stem from supplier capabilities and technology life cycle and advancement that either support outsourcing of standardized and lower value or more advanced and higher value activities (Gereffi et al., 2005; Sturgeon et al., 2008). Technology characteristics are reflected in the determinants of transaction complexity (the amount of information to be exchanged between partners) and transaction codification (the level of formalization). The supplier capability is not clearly defined in the GVC concept: however, considering the theoretical context, they represent a supplier's resources and competences to meet the customer's requirements (Gereffi et al., 2005; Sturgeon et al., 2008; Pietrobelli \& Rabellotti, 2011).

Considering the above determinants, captive networks emerge in the case of high transaction complexity and codification and low supplier capabilities (Gereffi et al., 2005). Modular network governance applies when transaction complexity, technology codification, and supplier capabilities are high. Relational networks, in turn, are adopted in transactions with high complexity but low codification, and when subcontractor capabilities are high (Humphrey \& Schmitz, 2004b; Winter, 2010; Gereffi et al., 2005).

The extant research points to the specialization and hierarchization of global relationships among clusters representing either higher value adding activities, such as research and development, engineering, design, marketing and value chain coordination, or lower value adding functions, such as manufacturing standardized products and assembling.

Therefore, how can cluster upgrading be accomplished according to the GVC views?

The GVC proposes that upgrading stems from the cluster firms' global collaborations. The governance mode set up by the large global customers impacts the development prospects of suppliers. However, the type of governance is not only dependent on the choices of powerful corporations from advanced economies. These choices are also dependent on the technology life cycle and advancement that turns into the level of transaction complexity and codification, as well as on supplier capabilities.

In the theoretical framework of the GVC, the issue of capabilities poses a threat of tautology, just as the entire capability or resource-based approach. Namely, the essence of upgrading is in the supplier's capability advancement and the latter one, as pointed out earlier, would also be dependent on supplier capabilities that affect the choice of governance. This tautology can be resolved, if we assume that capabilities are mediated by the life cycle of 
specific cooperation. Namely, at the start of cooperation, we can consider the initial capabilities of a supplier that determine the governance mode beside transaction complexity and codification. The resulting governance directly impacts the prospects for supplier upgrading. However, another problem is determinism of a governance mode if a supplier starts with captive governance mode. Once established, the governance would eventually determine learning and development of a supplier as a trap or lock-in. Considering this, the GVC governance would not be able to explain the evolution from captive networks to relational or modular networks, which has been observed in reality. This would require introducing additional factors that enable modification of the established governance towards more advanced modes, during the course of cooperation (Kaplinsky \& Morris, 2001; Tsang, 2000; Foss \& Foss, 2005; Williamson, 1991, 1999).

\section{The resource-based perspective on cluster upgrading}

More recent views on cluster upgrading propose the role of supplier capabilities not only in the initial phase of cooperation, but also throughout its course (Kaplinsky \& Morris, 2001; Gereffi et al., 2005). Namely, absorptive capacity and dynamic capabilities are emphasized as drivers of cluster upgrading (Samarra \& Belussi, 2006; Cusmano et al., 2010; Pietrobelli \& Rabellotti, 2011; Munari et al., 2012; Menghinello et al., 2010; Aslesen \& Hirarchi, 2015; De Marchi et al., 2018). These developments signal refocusing from the GVC governance as a set of conditions external to clusters, towards cluster internal characteristics and dynamics. Alike the GVC governance, this view adopts a micro-perspective of firms forming industrial agglomerations. It is positive in nature since it points to the importance of resources and competences of firms forming clusters rather, than to specific decision types. As a result, the research focus changes from governance mode as a direct determinant of firm upgrading, towards the antecedents of the evolution of governance structures, and to factors that enable benefitting from governance solutions. This approach is in line with the resource-based view (the RBV) of the firm or the capability perspective as a broad approach that stresses the relevance of internal capabilities over environmental factors for the firm's competitive advantage (Penrose, 1959; Cohen \& Levinthal, 1990; Kogut \& Zander, 1992; Peteraf, 1993; Barney, 1999; Teece, 2007).

The RBV originated as a theory of learning and growth (Penrose, 1959; Wernerfelt, 1984; Kogut \& Zander, 1992; Barney, 1999), thus its recent focus on absorptive capacity and dynamic capabilities. Dynamic capabilities are considered as the ability to integrate, build and reconfigure internal and external competences in response to environmental changes (Teece, 
2007; Helfat et al., 2007; Di Stefano, Peteraf, \& Verona, 2010). They ensure new, more efficient solutions by adapting or replacing the existing routines and practices (Zahra, Sapienza, \& Davidsson, 2006) and are conducive to knowledge exploration and radical innovative activity (Sirén, Kohtamäki, \& Kuckertz, 2012). Absorptive capacity forms conditions for adopting new ways of functioning and it establishes a basis for dynamic capabilities to act (Cohen \& Levinthal, 1990; Munari et al., 2012). Absorptive capacity represents the ability to absorb and internalize external knowledge (Cohen \& Levinthal, 1990; Zahra \& George, 2002; Ahlin, Drnovšek, \& Hisrich, 2014). Both dynamic capabilities and absorptive capacity concepts are evolutionary and pathdependent: therefore their impact and outcomes need to be mediated by a time factor (Sirén et al., 2012).

In the literature on cluster dynamics, including the concepts of life cycle, evolution, and eventually, upgrading, it is posited that absorptive capacity and dynamic capabilities largely determine the growth and competitive advantage of industrial agglomerations (Pietrobelli \& Rabellotti, 2011; Aslesen \& Harirchi, 2015). They are critical for transferring technological and management knowledge between large customers from advanced economies and their suppliers and subsidiaries in clusters from less developed countries (Munari et al., 2012; Pietrobelli \& Rabellotti, 2011; Hervas-Oliver et al., 2012). The research on clusters and foreign direct investment in emerging markets, such as Central East European countries, confirms the importance of these factors on upgrading regional economies (Gorynia, Nowak, \& Wolniak, 2007; Pisoni, Fratocchi, \& Onetti, 2013). Moreover, the link is emphasized between more balanced and reliability-based relationships and higher levels of transaction technology and supplier competence (Lungwitz \& Campagna, 2006).

Consequently, the RBV proposes that cluster upgrading depends on the level of absorptive capacity and dynamic capabilities demonstrated by cluster firms. Absorptive capacity and dynamic capabilities are conditions for learning processes and they enable progressive changes in the governance of customer-supplier relationships.

\section{Cluster life cycle and evolution and the prospects for upgrading}

Alternatively to the micro- or firm-level perspective of GVCs and the RBV, the approaches of cluster life cycle and evolution offer an industrylevel perspective on cluster progressive dynamics, including upgrading. These are positive approaches to the phenomenon of upgrading as they focus on investigating complex mechanisms and processes rather than on normative recommendations of specific decisions and choices leading to the improvement of cluster competitive position in international exchange. In its 
traditional form, the evolutionary and life cycle views on cluster advancement predominantly focus on group processes linking actors, territories and networks (Fornahl, Hassink, \& Mentzel, 2015). These complex systems are analyzed with the use of such concepts of evolutionary economics as myopia, path-dependence, and isomorphism, that channel group processes in clusters into some established pathways, conditioned by prior events (Martin \& Sunley, 2006; Maskell \& Malmberg, 2007; Mentzel \& Fornahl, 2010; Ter Wal \& Boschma, 2011). Firms predominantly are not considered as individual units but as groupings of interconnected entities that undergo joint development processes. According to evolutionary approaches, cluster upgrading prospects depend on the stage of this cluster's life cycle and evolution.

Theories of network and technology life cycles are a grounding for the cluster life cycle approach (Mentzel \& Fornahl, 2010; Tushman \& Rosenkopf, 1992). According to this approach, the level of technological heterogeneity of firms and the level of network openness and flexibility mark the emergence, growth, sustainment, decline or renewal of industrial agglomerations. The best prospects for upgrading are in the growth phase. In this phase the technological specialization of companies is moderate and networks are flexible and open to external knowledge through cross-border links (Ter Wal \& Boschma, 2011). These characteristics are also typical of the start of new cycle (recovery) and further growth after periods of sustainment or decline (Hassink, 2005; Frenken, 2007; Neffke et al., 2011). In the decline stage, when firms' technological profiles become strongly homogenous, focused and bound by closed, rigid networks, the opportunities for upgrading are low. The phases of emergence (high technological heterogeneity but low networking interaction) and sustainment (low technological heterogeneity but networks open to external synergies) are featured by moderate possibilities of upgrading (Ter Val \& Boschma, 2011).

The concept of cluster evolution puts emphasis on the role of firm capabilities and networks, which facilitate knowledge spill-overs inside the cluster and in its external, international environment (Ter Wal \& Boschma, 2011). Alike the life cycle approach, the model of cluster evolution assumes development stages. However, it is less deterministic than the concept of life cycle and therefore more realistic. Moreover, this framework is more open to the role of external networks and relocation processes that result either in the dispersal of the activities formerly concentrated in clusters from developed economies, or in the emergence of new clusters in less developed economies (Hassink, 2005). The prospects for upgrading are high in the growth stage and renewal (new growth) stage that might take place after maturity and decline. Growth is accomplished due to the infusion of knowledge through networks centered on focal firms, provided that these networks are dense both inside 
and outside the cluster. The prospects for upgrading are moderate in the introductory stage (flexible, social networks but weak business networks, variety of firm capabilities) and in the maturity stage (stable networks around focal firms but decreasing variety of firm capabilities due to shake-out). Decline offers low possibilities of upgrading due to technological rigidity (low variety of firm capabilities) and network rigidity.

Table 1. Cluster upgrading prospects according to the concepts of cluster life cycle and cluster evolution

\begin{tabular}{|c|c|c|}
\hline Upgrading prospects & Cluster life cycle stages & Cluster evolution stages \\
\hline Moderate & $\begin{array}{l}\text { Emergence } \\
\text { (technological } \\
\text { heterogeneity of firms, } \\
\text { low interaction) }\end{array}$ & $\begin{array}{l}\text { Introductory stage (flexible, } \\
\text { social networks but weak } \\
\text { business networks, variety of } \\
\text { firm capabilities) }\end{array}$ \\
\hline High & $\begin{array}{l}\text { Growth (focusing on } \\
\text { technology of firms, } \\
\text { open and flexible } \\
\text { networks) }\end{array}$ & $\begin{array}{l}\text { Growth stage (stabilizing core- } \\
\text { periphery profile of networks, } \\
\text { dense networks inside the } \\
\text { cluster, possibility of stable and } \\
\text { dense knowledge networks } \\
\text { dispersed to other locations) }\end{array}$ \\
\hline Moderate & $\begin{array}{l}\text { Sustainment (focused } \\
\text { technology, open } \\
\text { networks benefiting from } \\
\text { synergies and external } \\
\text { knowledge) }\end{array}$ & $\begin{array}{l}\text { Maturity stage (stable core- } \\
\text { periphery profile of networks, } \\
\text { decreasing variety of firm } \\
\text { capabilities due to shake-out) }\end{array}$ \\
\hline Low & $\begin{array}{l}\text { Decline (strongly focused } \\
\text { technology, closed } \\
\text { networks impede cluster } \\
\text { adaptability) }\end{array}$ & $\begin{array}{l}\text { Industry decline (network } \\
\text { rigidity, technological lock-in) }\end{array}$ \\
\hline High & $\begin{array}{l}\text { The start of a new cycle } \\
\text { (new technological } \\
\text { heterogeneity, strong } \\
\text { networks sourcing } \\
\text { external knowledge) }\end{array}$ & $\begin{array}{l}\text { Renewal (the importance of } \\
\text { dynamic capabilities in relocating } \\
\text { to new regions or in changing } \\
\text { position in the network) }\end{array}$ \\
\hline
\end{tabular}

To sum up, both life cycle and evolutionary approaches recommend a moderate level of technological variety in networks to accomplish cluster upgrading (Fornahl et al., 2016; Gancarczyk, 2015). Too low a variety would not ensure new products and industries to branch out. Too high a variety would prevent economies of scope and scale and exploiting an extant resource base. Regarding network characteristics, open and flexible networks with balanced and dispersed power support upgrading, while rigid and centralized governance 
prevents cluster advancement towards new, higher value adding activities (Fornahl et al., 2015; Gancarczyk, 2015a, 2015b; Gancarczyk \& Gancarczyk, 2018).

As earlier noted, the evolutionary view proposes that cluster upgrading depends on the stage of cluster life cycle or evolution. However, this relationship is indirect and mediated by network structure as well as technological heterogeneity and variety of firms' capabilities. Namely, the type of network governance and capability of firms have direct effects on introducing new products, services, and functions, or sticking to the established paths and rigid exploitation of extant capabilities. This view corresponds with the concept of cluster upgrading in the GVC and the RBV to be dependent on the network governance and capabilities, accordingly.

\section{The impact of lead firms on cluster upgrading}

The emphasis on network governance and capabilities was a natural background for a new focus in cluster upgrading that underlines the role of lead or focal firms (Frenken 2007; Mentzel \& Fornahl, 2010, Ter Wal \& Boschma, 2011). According to this view, individual firms with superior capabilities act as network leaders and their choices impact the development paths of networks and the entire industrial agglomerations. The lead firms, through expansion and spin-offs, drive the cluster specialization and build its internal strength (Best, 2000; Penrose, 1959). Their growth mechanism consists of matching capabilities with environmental opportunities (Penrose, 1959; Best, 2001; Gancarczyk \& Gancarczyk, 2016). To better exploit the opportunities they form alliances with competitors and focus on core and higher value-adding activities, while outsourcing or spinning-off those lower value and standardized (Huggins \& Johnston, 2010; Barney, 1999). As a result, the collaborative and competitive networks emerge around focal companies, ensuring knowledge exchange and creation (Maskell \& Malmberg, 1999; Alegre, Sengupta \& Lapiedra, 2013; Lisowska, 2015; Gancarczyk \& Gancarczyk, 2016). Cluster networks are repositories of strategic resources, including knowledge conducive for innovation and further growth (Gulati, 2007; Huggins \& Johnston, 2010; Hansen, 2002; Owen-Smith \& Powell, 2004). This raises a mutual dependence between firms and their networks in clusters and focal companies plan growth and make strategic choices considering their own capabilities and complementary resources stored in their networks (Francioni, Musso \& Vardiabasis, 2013). Following this, the research on the expansion and strategic decisions of cluster lead firms is a normative perspective that seeks recommendations as to firm-level choices that affect upgrading or downgrading of industrial agglomerations. 
The major strategic choices in recent years were about internationalization of production function by cluster leaders (Li, Bathelt, \& Wang, 2012; Biggiero, 2006; Alberti, 2006; Lorentzen, 2008; De Propris, Menghinello, \& Sugden, 2008; Samarra \& Belussi, 2006). On the one hand, this process was necessitated by the need to search for cost-effective inputs and sources of technology in the face of the increasing global competition. Dense internal networks are valuable as knowledge repositories. However, they might also suffer from rigidity and excessive specialization leading to regional lock-in and inability to diversify into higher value and more prospective industries (Grabher, 1993; Hsu \& Lin, 2011). Focal firms took the roles of global pipelines to access new markets and technologies (Hassink, 2005; Aslesen \& Harirchi, 2015; Alegre et al., 2013; Lisowska, 2015; Gancarczyk \& Gancarczyk, 2016). On the other hand, the relocation, i.e., moving the elements of cluster value chains out of the source agglomeration, caused structural changes in the production systems and networks. Decomposing the local knowledge and production networks threatened the extant competitive advantage and often led to a decline in the cluster life cycle (Alberti, 2006; Samarra \& Belussi, 2006). In order to combine the advantages of internationalization and extant cluster capabilities, selective relocation is recommended in the area of activities and functions that are noncore, while retaining the most advanced, knowledge-intensive manufacturing and services (Biggiero, 2006; Gancarczyk \& Gancarczyk, 2018; De Propris et al., 2008). This kind of relocation strategy might be a good grounding for new growth or renewal in the cluster life cycle or evolution.

To sum up, the research on the role of cluster lead firms proposes that the upgrading of industrial agglomerations depends on the internationalization strategies of these enterprises. The international strategies of focal firms affect cluster capabilities, governance, as well as life cycles and evolution. The focal firms should adopt the strategic objectives directed both at the avoidance of regional lock-in through external collaboration, and at the retention and development of the capabilities of the source cluster.

\section{Policy interventions approach to cluster upgrading}

The successful transition from lower value-adding to higher value activities is often supported by public policies (Humphrey etal., 2018). As the advancement to higher value activities always involves innovations in the area of new products, processes and functions, the support for cluster upgrading belongs predominantly to innovation policies (Lema, Rabellotti, \& Sampath, 2018). Particularly, regional innovation systems and smart specialization strategies are conducive to the accomplishment of upgrading (De Marchi et al., 2018; Pietrobelli \& Rabellotti, 2011). The innovation systems policies were found to 
be instrumental for the progressive shift from assembling and manufacturing of standardized components to advanced manufacturing, engineering and design in the Taiwanese computer industry, as well as from manufacturing to design, branding, and marketing in the Brazilian and Mexican shoe industries, among others (Pietrobelli \& Rabellotti, 2011). The core of these policies was to integrate the efforts of firms, regional governments, and universities to act as a system directed at innovation development (Pietrobelli \& Rabellotti, 2004). Smart specialization strategies consist of specialized diversification and branching out related industries to avoid rigid specialization and lockin (Foray, 2014). The new industries are technologically more advanced and thus either replace the older industries or improve their efficiency and refresh product or service offerings (Foray, 2013; 2017). The innovation policies based on smart specialization promote the internationalization and insertion of clusters to global value chains through setting up collaboration platforms and promoting partnerships among clusters (European Commission, 2016).

The advancements of firms and industries were accomplished with public involvement in developing cluster capabilities, framing the GVC governance conditions for knowledge transfer and learning, as well as driving the cluster life cycle or evolution towards new cycles or renewal.

In the area of capability development, public initiatives should be directed at education, encouraging collaboration among different actors in the innovation system, and at R\&D investment (Humphrey et al., 2018). Public-private venture funds could be a tool for high-risk innovation projects (European Commission, 2016). Moreover, the support for retaining major product and process innovations in the region would protect the cluster from knowledge leakage and imitations (Aslesen \& Harirchi, 2015).

In the area of the GVC governance conditions, it is recommended that higher value-adding activities are attracted to clusters, such as $R+D$ centers, engineering laboratories, and advanced manufacturing (Rugraff, 2010). In captive production networks, local small and medium-sized enterprises (SMEs) from lower cost locations occupy a weak position in relation to large foreign investors and have minor possibilities of learning and absorbing knowledge (Gereffi et al., 2005). Regional governments need to work with SMEs and large transnational firms to set up better outsourcing conditions (Gereffi \& Lee, 2018). This can be supported by embedding the branches of foreign direct investors with long-term contracts to facilitate knowledge absorption by cluster firms. Possible solutions include developing complex projects locally, such as technology parks, creating favorable infrastructural and institutional conditions, and marketing the regional specialization to create the cluster image in specialized business areas (European Commission, 2016; Humphrey et al., 2018). 
Driving the cluster evolution towards a growth stage of the life cycle requires sourcing external knowledge based on deepened and durable networking with collaborators, both out of the agglomeration and within the cluster (Hassink, 2005). Regional governments are encouraged to act as accelerators and mediators in setting up collaboration platforms, including on-line sites, symposia, exhibitions, and fairs. Since both specialization and heterogeneity of technologies are favorable for growth and new grow (new life cycle), the implementation of smart specialization strategies is an appropriate direction for public policies (European Commission, 2016; Pietrobelli \& Rabellotti, 2011). The development of smart specialization, in turn, needs to be supported with inward foreign investment in the areas that are crucial for this specialization (Foray, 2014).

Due to combining regional and global foci, the implementation of cluster upgrading policies includes multi-level actors from regional, national, and international institutions (Gereffi \& Lee, 2016). For instance, the improvement of the work and contract conditions for local employees and companies outsourcing to global buyers requires the engagement of national authorities that set labor and contract conditions, regional authorities to establish investment opportunities and regulations, as well as international organizations, such as International Labour Organization.

To sum up, the public interventions approach to cluster upgrading proposes that government policies focus on the development of cluster capabilities, framing favorable GVC governance, and stimulating the cluster life cycle and evolution toward growth or renewal stages. In those interrelated areas, specific measures are recommended, with a focus on innovations systems and smart specialization strategies. The implementation of cluster upgrading in GVCs should engage public actors across multi-level government.

\section{A framework for studying the antecedents of cluster upgrading}

In the preceding sections, we have discussed five approaches that propose antecedents of cluster upgrading within global value chains. These approaches demonstrated distinctive but interrelated causes of advancing the positions of industrial agglomerations, according to positive or normative profiles. The positive stream is represented by the GVC governance approach, the RBV, as well as the concepts of cluster life cycle and evolution. The GVC governance approach puts emphasis on firm-level governance relationships and a positive explanation of how different types of governance affect the advancement of cluster position. However, it is also acknowledged that the governance setup is conditioned by the initial level of supplier capabilities. The capability-related antecedents of cluster dynamics are reflected in the resource-based view, 
according to which capabilities are generic antecedents of the governance type, and ultimately, the progress in industrial agglomerations. It should, however, be recognized that the RBV acknowledges the opposite causality, namely, the value of networking relationships in developing capabilities through knowledge transfer and exchange. The RBV offers a positive and firm-level explanation of how clusters improve their positions in GVCs. The positive perspective is also represented by the evolutionary and life-cycle concepts of cluster progressive dynamics, although, this perspective takes a broader view of industries and group processes. Industry life cycles and evolution affect the upgrading indirectly, as a context formed by complex factors of governance, particularly the role of networks, and capabilities.

The approaches that stress the role of lead firms and public interventions as antecedents of cluster upgrading represent the normative research stream. Both the research on focal firms and public interventions draw upon the accomplishments of the positive studies. These studies identify three interdependent variables of capabilities, governance and life cycles or evolutions as the major antecedents of upgrading. The normative research investigates how lead firms and public policies should affect the three determinants to ensure a progressive change of the cluster position in GVCs.

The positive and normative streams of research on cluster upgrading and their interrelations form a framework for studying the antecedents of the upgrading phenomenon (Figure 1).

$\begin{array}{ccc}\begin{array}{c}\text { POSITIVE STREAM of } \\ \text { the research }\end{array} & \begin{array}{c}\text { ANTECEDENTS of } \\ \text { cluster upgrading }\end{array} & \text { NORMATIVE } \\ \text { on cluster upgrading } & \text { STREAM } \\ \text { of the research } \\ \text { on cluster upgrading }\end{array}$

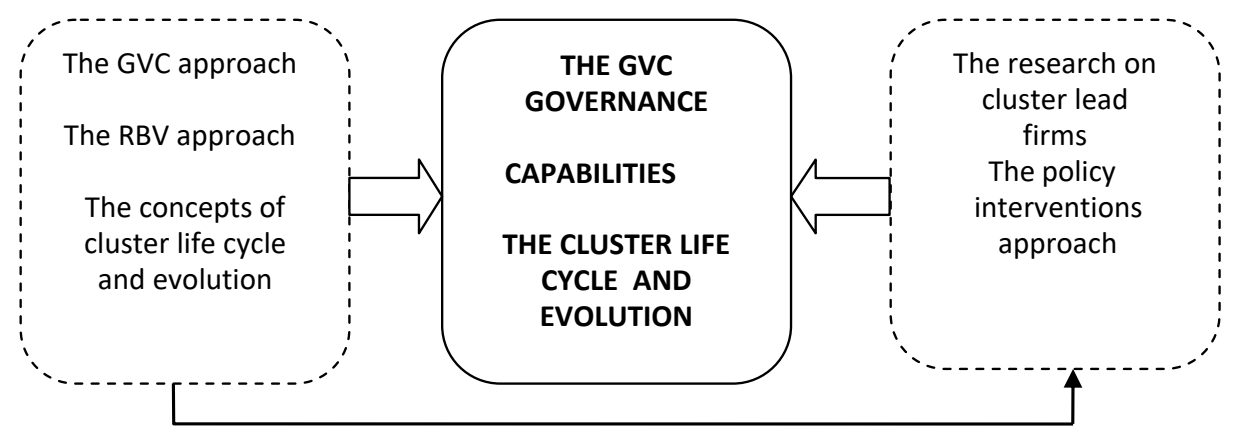

Figure 1. A framework for studying the antecedents of cluster upgrading 
Figure 1 underlines the feedback relations between the positive and normative streams. The positive stream explains governance, capability, and life cycle or evolutionary antecedents of upgrading. It provides the knowledge of the determinants of this process. This knowledge forms the basis for the normative streams that should guide the private choices of lead firms and public policy interventions. The strategies of lead firms and policy interventions are directed at the improvement of the capability and governance conditions, and on framing the evolutionary pathways and life cycles of industrial agglomerations.

The above relationships between research streams enable us to formulate the questions for further studies that would integrate extant accomplishments. The current stage of the positive research stream calls for concurrent investigation of all three groups of antecedents within one research experiment. Since the three groups of variables need to be studied, it is important to identify a possible hierarchy, causal relationship among these variables, as well as mediators and moderators of their influence on cluster upgrading. Consequently, we formulate the first research question:

RQ1. What is the hierarchy of importance and causal relationship among capabilities, governance, and the phase of life cycle or evolution in the process of cluster upgrading?

The normative research stream relies upon the findings from the positive stream, but its primary focus is on the recommendations about private choices of lead firms and public interventions to improve the capability and governance conditions, as well as to frame the cluster evolution or life cycle toward upgrading. Therefore, we propose the next set of research questions:

RQ2. How can the strategies of lead firms affect cluster capabilities, governance, and the phase of life cycle or evolution toward cluster upgrading?

RQ2. How can public policies stimulate cluster capabilities, governance, and the phase of life cycle or evolution toward cluster upgrading?

\section{DISCUSSION AND CONCLUSION}

In this paper, we identified and systemized the research streams in regional cluster upgrading, the phenomenon and concept discussed in political economics, economic geography, as well as entrepreneurship and regional 
development (Gereffi et al. 2005; Aslesen \& Harirchi, 2015; Sturgeon, 2003). Within extant studies on regional clusters, the upgrading concept brings the value of prospective implications, important for planning regional growth in global value chains (European Commission, 2016; Gereffi \& Lee, 2018). Based on the narrative literature review, we discussed the major approaches to the antecedents of cluster upgrading and synthesized their propositions. Following this we systemized the approaches into positive and normative streams, pointing to their interrelations. This analytical procedure resulted in an integrative framework for studying the antecedents of cluster upgrading and the questions for further research.

The paper contributes to the literature in cluster dynamics, particularly to upgrading the position of industrial agglomerations in GVCs (Gereffi et al. 2015; Gereffi \& Lee, 2018; De Marchi et al., 2018). The first contribution consists of a comprehensive approach to the cluster upgrading theory by integrating the research fragmented into a number of distinctive but interrelated approaches. These approaches included the GVC governance literature, the resource-based view, evolutionary and life cycle concepts, lead firm strategies, and policy interventions. Our synthesis serves knowledge accumulation and advancement by recognizing the extant accomplishments and setting up further research directions (Hoon, 2013; Thomas \& Harden, 2008). The second contribution includes a theoretical framework and research questions that stem from it. The framework points to the relationships between positive and normative streams, an issue often overlooked by policy-makers that should draw from the explanatory studies of a positive nature (Foray, 2014). On the other hand, the community of academia needs to recognize the role of positive research as a grounding for policy directions and instruments (Fornahl \& Hassink, 2017). The research questions we propose acknowledge this mutually benefitting relation between positive and normative studies, as well as pointing to major variables to be studied explicitly within one research experiment and not separately. This integrative approach should result in establishing the hierarchy of the antecedents of cluster upgrading, causal relationships among them, as well as moderators and mediators of their influence (Leavitt et al., 2010). Moreover, they can be of relevance both for academia and policy-makers to set up a collaborative agenda and feedback between positive and normative objectives (Fornahl \& Hassink, 2017).

Finally, the limitations of our study should be explained, as well as research implications that stem from them. The study suffers from the shortcoming common to narrative literature reviews, namely, from the subjective choice of literature sources (Green et al., 2006). This subjectivism was alleviated by clearly setting up the scope of the literature review, the aim, and the research procedure (Jones, 2004). Moreover, the narrative 
review was a necessary compromise due to the aim of the study to bridge and systemize a broad literature on the progressive dynamics in the context of GVCs (Green et al., 2006, Jones, 2004). The introductory stage of the research and the scope of literature prevented research profiling methods and systematic literature reviews. These methods require a more focused research theme and search criteria to process the data using quantitative techniques. However, the outcomes of our research may serve as a starting point for systematic reviews, research profiling and exploratory empirical research (Hoon, 2013; Thomas \& Harden, 2008).

\section{Acknowledgments}

This paper is a result of the international project "EU Regional and Innovation Policies and Peripheral Regions (EURIPER)," co-financed by the European Commission under the Jean Monnet Projects Action of the Erasmus+ Programme (Project Reference: 587410-EPP-1-2017-1-ES-EPPJMO-PROJECT).

\section{References}

Agostino, M., Giunta, A., Nugent, J. B., Scalera, D., \& Trivieri, F. (2015). The importance of being a capable supplier: Italian industrial firms in global value chains. International Small Business Journal, 33(7) 708-730.

Ahlin, B., Drnovšek, M., \& Hisrich, R. D. (2014). Exploring the moderating effects of absorptive capacity on the relationship between social networks and innovation. Journal for East European Management Studies, 19(2), 213-235.

Alberti, F. G. (2006). The decline of the industrial district of Como: Recession, relocation or reconversion? Entrepreneurship \& Regional Development, 18(6), 473-502.

Alegre, J., Sengupta, K., \& Lapiedra, R. (2013). Knowledge management and innovation performance in a high-tech SMEs industry. International Small Business Journal, 31(4), 454-470.

Argyres, N. S., \& Zenger, T. R. (2012). Capabilities, transaction costs, and firm boundaries. Organization Science, 23(6), 1643-1657.

Asheim, B. T., \& Isaksen, A. (2003). SMEs and the regional dimension of innovation. In B.T. Asheim, A. Isaksen, C. Nauvelaers, \& T. Tödtling, Regional Innovation Policy for Small-Medium Enterprises (pp.49-77). Cheltenham: Edward Elgar.

Aslesen, H. W., \& Harirchi, G. (2015). The effect of local and global linkages on the innovativeness in ICT SMEs: Does location-specific context matter? Entrepreneurship \& Regional Development, 27(9-10), 644-669.

Aspers, P. (2010). Using design for upgrading in the fashion industry. Journal of Economic Geography, 10(6), 189-207.

Barney, J. B. (1999). How a firm's capabilities affect boundary decisions. MIT Sloan Management Review, 40(3), 137. 
Bellandi, M. (2001). Local development and embedded large firms. Entrepreneurship \& Regional Development, 13(3), 189-210.

Best, M. H. (2000). Silicon Valley and the resurgence of Route 128: Systems integration and regional innovation. In J.H. Dunning (Ed.), Regions, Globalization and the Knowledge-Based Economy (pp. 459-484). Oxford: Oxford University Press.

Biggiero, L. (2006). Industrial and knowledge relocation strategies under the challenges of globalization and digitalization: The move of small and medium enterprises among territorial systems. Entrepreneurship \& Regional Development, 18(6), 443-472.

Boschma, R., \& Fornahl, D. (2011). Cluster evolution and a roadmap for future research. Regional Studies, 45(10), 1295-1298.

Brusco, S. (1982). The Emilian model: Productive decentralisation and social integration. Cambridge Journal of Economics, 6(2), 167-184.

Cohen, W. M., \& Levinthal, D. A. (1990). Absorptive capacity: A new perspective on learning and innovation. Administrative Science Quarterly, 35(1), 128-152.

Collins, J. A., \& Fauser, B. C. (2005). Balancing the strengths of systematic and narrative reviews. Human Reproduction Update, 11(2), 103-104.

Combs, J. G., Ketchen Jr, D. J., Crook, T. R., \& Roth, P. L. (2011). Assessing cumulative evidence within 'macro' research: Why meta-analysis should be preferred over vote counting. Journal of Management Studies, 48(1), 178-197.

Cusmano, L., Mancusi, M. L., \& Morrison, A. (2010). Globalization of production and innovation: How outsourcing is reshaping an advanced manufacturing area. Regional Studies, 44(3), 235-252.

De Marchi, V., Giuliani, E., \& Rabellotti, R. (2018). Do Global Value Chains offer developing countries learning and innovation opportunities? The European Journal of Development Research, 30(3), 389-407.

De Propris, L., Menghinello, S., \& Sugden, R. (2008). The internationalization of production systems: Embeddedness openness and governance. Entrepreneurship \& Regional Development, 20(6), 489-493.

Di Stefano, G., Peteraf, M., \& Verona, G. (2010). Dynamic capabilities deconstructed: A bibliographic investigation into the origins, development, and future directions of the research domain. Industrial and Corporate Change, 19(4), 1187-1204.

European Commission (2002). Regional clusters in Europe, Observatory of European SMEs, (2). Luxembourg: Office for Official Publications of the European Communities.

European Commisssion (2016). Smart guide to cluster policy. Guidebook Series: How to support SMEs through Structural Funds.

Foray, D. (2013). The economic fundamentals of smart specialisation. Ekonomiaz, 83(2), 83-102.

Foray, D. (2014). Smart specialisation: Opportunities and challenges for regional innovation policy. UK: Routledge.

Foray, D. (2017). The economic fundamentals of smart specialization strategies. In S. Radosevic, A. Curaj, R. Gheorghiu, L. Andreescu, \& I. 
Wade (Eds.), Advances in the Theory and Practice of Smart Specialization (pp. 38-50). UK: Academic Press.

Fornahl, D., \& Hassink, R. (Eds.). (2017). The Life Cycle of Clusters: A Policy Perspective. Cheltenham: Edward Elgar Publishing.

Fornahl, D., Hassink, R., \& Menzel, M. P. (Eds.) (2015). Broadening our Knowledge on Cluster Evolution. US: Taylor \& Francis.

Foss, K., \& Foss, N. (2005). Resources and transaction costs: How property rights economics furthers the resource-based view. Strategic Management Journal, 26(6), 541.

Francioni, B., Musso, F., \& Vardiabasis, D. (2013). Key decisions and changes in internationalization strategies: The case of smaller firms. Journal of Strategic Marketing, 21(3), 240-259.

Frenken, K. (2007). Applied Evolutionary Economics and Economic Geography. Cheltenham: Edward Elgar Publishing.

Gancarczyk, M. (2015a). Enterprise- and industry-level drivers of cluster evolution and their outcomes for clusters in developed and less developed countries. European Planning Studies, 23(10), 1932-1952.

Gancarczyk, M. (2015b). Proces wzrostu przedsiębiorstwa w świetle podejścia zasobowego i teorii kosztów transakcyjnych. Gospodarka Narodowa, 5(279), 5-31.

Gancarczyk, M., \& Gancarczyk J. (2016). SME Supplier upgrading during the cooperation life cycle - evidence from Central and Eastern Europe. Journal for East European Management Studies, 21(3), 318-351.

Gancarczyk, M., \& Gancarczyk, J. (2008). Czynniki Rozwoju Przedsiębiorczości w Województwie Małopolskim. Kraków: Urząd Marszałkowski Województwa Małopolskiego.

Gancarczyk, M., \& Gancarczyk, J. (2013). Structural change in industrial clustersscenarios and policy implications. Studia Regionalia, (35), 111-127.

Gancarczyk, M., \& Gancarczyk, J. (2018). Proactive international strategies of cluster SMEs. European Management Journal, 36(1), 59-70.

Gancarczyk, M., Gancarczyk, J., \& Bohatkiewicz, J. (2017). SME roles in modular value chains: Perspectives for growth and innovativeness. Entrepreneurial Business and Economics Review, 5(3), 95-117.

Geodecki, T., \& Grodzicki, M. (2015). Jak awansować w światowej lidze gospodarczej? Kraje Europy Środkowo-Wschodniej w globalnych łańcuchach wartości. Zarzq̨dzanie Publiczne, 3, 16-40.

Gereffi, G. (1996). Global commodity chains: New forms of coordination and control among nations and firms in international industries. Competition \& Change, 1(4), 427-439.

Gereffi, G., \& Lee, J. (2016). Economic and social upgrading in global value chains and industrial clusters: Why governance matters. Journal of Business Ethics, 133(1), 25-38.

Gereffi, G., Humphrey, J., \& Sturgeon, T. (2005). The governance of global value chains. Review of International Political Economy, 12(1), 78-104. 
Glückler, J. (2007). Economic geography and the evolution of networks. Journal of Economic Geography, 7(5), 619-634.

Gorynia, M., Nowak, J., Howak, J., \& Wolniak, R. (2007). Motives and modes of FDI in Poland: An exploratory qualitative study. Journal for East European Management Studies, 12(2), 132-151.

Grabher, G. (1993). The weakness of strong ties: The lock-in of regional development in the Ruhr area. In G. Grabher, The Embedded Firm: On the Socioeconomics of Industrial Network (pp. 124-165). London: Routledge.

Green, B. N., Johnson, C. D., \& Adams, A. (2006). Writing narrative literature reviews for peer-reviewed journals: Secrets of the trade. Journal of Chiropractic Medicine, 5(3), 101-117.

Gulati, R. (2007). Managing Network Resources: Alliances, Affiliations, and Other Relational Assets. Oxford: Oxford University Press on Demand.

Hansen, M. T. (2002). Knowledge networks: Explaining effective knowledge sharing in multiunit companies. Organization Science, 13(3), 232-248.

Helfat, C. E., Finkelstein, S., Mitchell, W., Peteraf, M., Singh, H., Teece, D., \& Winter, S. G. (2009). Dynamic Capabilities: Understanding Strategic Change in Organizations. UK: John Wiley \& Sons.

Hervas-Oliver, J. L., Albors-Garrigos, J., de-Miguel, B., \& Hidalgo, A. (2012). The role of a firm's absorptive capacity and the technology transfer process in clusters: How effective are technology centres in low-tech clusters? Entrepreneurship \& Regional Development, 24(7-8), 523-559.

Hoon, Ch. (2013). Meta-synthesis of qualitative case studies: An approach to theory building. Organizational Research Methods 16(4), 522-546.

Hsu, J-Y., \& Lin, L-X. (2011). The leader firms and the evolution of an industrial district: A case study of hosiery district in Taiwan. European Planning Studies, 19(6), 1021-1041.

Huggins, R., \& Johnston, A. (2010). Knowledge flow and inter-firm networks: The influence of network resources, spatial proximity and firm size. Entrepreneurship \& Regional Development, 22(5), 457-484.

Humphrey, J., \& Schmitz, H. (2002). How does insertion in global value chains affect upgrading in industrial clusters? Regional Studies, 36(9), 1017-1027.

Humphrey, J., \& Schmitz, H. (2004a). Governance in global value chains. In H. Schmitz, Local Enterprises in the Global Economy (pp. 96-109). Cheltenham: Edward Elgar.

Humphrey, J., \& Schmitz, H. (2004b). Chain governance and upgrading: Taking stock. In H. Schmitz, Local Enterprises in the Global Economy. (pp. 349381). Cheltenham: Edward Elgar.

Humphrey, J., Ding, K., Fujita, M., Hioki, S., \& Kimura, K. (2018). Platforms, innovation and capability development in the Chinese domestic market. The European Journal of Development Research, 30(3), 408-423.

Ivarsson, I., \& Alvstam, C. G. (2010). Upgrading in global value-chains: A case study of technology-learning among IKEA-suppliers in China and Southeast Asia. Journal of Economic Geography, 11(4), 731-752. 
Jones, K. (2004). Mission drift in qualitative research, or moving toward a systematic review of qualitative studies, moving back to a more systematic narrative review. The Qualitative Report, 9(1), 94-111.

Kaplinsky, R. \& Morris, M. (2001). Handbook For Value Chain Analysis. Retrieved from http://www.prism.uct.ac.za/papers/vchnov01.pdf Kaplinsky, R., Morris, M., \& Readman, J. (2002). Understanding Upgrading Using Value Chain Analysis. Retrieved from http://eprints.brighton.ac.uk/876/1/ Understanding_Upgrading_Using_Value_Chain_Analysis.pdf

Kirkevold, M. (1997). Integrative nursing research-an important strategy to further the development of nursing science and nursing practice. Journal of Advanced Nursing, 25(5), 977-984.

Kogut, B., \& Zander, U. (1992). Knowledge of the firm, combinative capabilities, and the replication of technology. Organization Science, 3(3), 383-397.

Krugman, P. (1991). Geography and Trade. Cambridge, MA: MIT Press.

Lager, T. (2000). A new conceptual model for the development of process technology in process industry: A point of departure for the transformation of the" process development process" into a formal work process? International Journal of Innovation Management, 4(03), 319-346.

Lam, A. (2007). Multinationals and transnational social space for learning: knowledge creation and transfer through global R\&D networks. In K.R. Polenske, The Economic Geography of Innovation (pp. 157-189). Cambridge: Cambridge University Press.

Leavitt, K., Mitchell, T. R., \& Peterson, J. (2010). Theory pruning: Strategies to reduce our dense theoretical landscape. Organizational Research Methods, 13(4), 644-667.

Lema, R., Rabellotti, R., \& Sampath, P. G. (2018). Innovation trajectories in developing countries: Co-evolution of Global Value Chains and innovation systems. The European Journal of Development Research, 30(3), 345-363.

Li, P. F., Bathelt, H., \& Wang, J. (2011). Network dynamics and cluster evolution: Changing trajectories of the aluminium extrusion industry in Dali, China. Journal of Economic Geography, 12(1), 127-155.

Lisowska, R. (2015). External determinants of the development of small and medium-sized enterprises - empirical analysis. Journal of Entrepreneurship, Management and Innovation, 11(4), 115-138.

Lorentzen, A. (2008). Knowledge networks in local and global space. Entrepreneurship \& Regional Development, 20(6), 533-546.

Lungwitz, R. E., Le, P., \& Campagna, S. (2006). Co-ordination media in crossnational networks of small and medium-sized enterprises. Journal for East European Management Studies, 11(4), 372-380.

Mackinnon, D. (2012). Beyond strategic coupling: Reassessing the firm-region nexus in global production networks. Journal of Economic Geography, 12(1), 227-245.

Malecki, E. J. (2010). Global knowledge and creativity: New challenges for firms and regions. Regional Studies, 44(8), 1033-1052. 
Markusen, A. (1996), Sticky places in slippery space: a typology of industrial districts. Economic Geography, 72(3), 293-313.

Martin, R., \& Sunley, P. (2006). Path dependence and regional economic evolution. Journal of Economic Geography, 6(4), 395-437.

Maskell, P., \& Malmberg, A. (1999). Localised learning and industrial competitiveness. Cambridge Journal of Economics, 23(2), 167-186.

Menghinello, S., De Propris, L., \& Driffield, N. (2010). Industrial districts, inward foreign investment and regional development. Journal of Economic Geography, 10(4), 539-558.

Menzel, M. P., \& Fornahl, D. (2010). Cluster life cycles-dimensions and rationales of cluster evolution. Industrial and Corporate Change, 19(1), 205-238.

Mudambi, R. (2008). Location, control and innovation in knowledge-intensive industries. Journal of Economic Geography, 8(5), 699-725.

Munari, F., Sobrero, M., \& Malipiero, A. (2012). Absorptive capacity and localized spillovers: Focal firms as technological gatekeepers in industrial districts. Industrial and Corporate Change, 21(2), 429-462.

Neffke, F., Henning, M., Boschma, R., Lundquist, K. J., \& Olander, L. O. (2011). The dynamics of agglomeration externalities along the life cycle of industries. Regional Studies, 45(1), 49-65.

Owen-Smith, J., \& Powell, W. W. (2004). Knowledge networks as channels and conduits: The effects of spillovers in the Boston biotechnology community. Organization Science, 15(1), 5-21.

Pavlínek, P. (2012). The internationalization of corporate R\&D and the automotive industry R\&D of East-Central Europe. Economic Geography, 88(3), 279-310.

Penrose, E. T. (1959). The Theory of the Growth of the Firm. New York: John Wiley. Peteraf, M. A. (1993). The cornerstones of competitive advantage: A resourcebased view. Strategic Management Journal, 14(3), 179-191.

Pietrobelli, C., \& Rabellotti, R. (2011). Global value chains meet innovation systems: Are there learning opportunities for developing countries? World Development, 39(7), 1261-1269.

Piore, M. J., \& Sabel C. (1984). The Second Industrial Divide: Possibilities For Prosperity. New York: Basic Books.

Pisoni, A., Fratocchi, L., \& Onetti, A. (2013). Subsidiary autonomy in transition economies: Italian SMEs in Central and Eastern European countries. Journal for East European Management Studies, 18(3), 336-370.

Porter, M. E. (1990). Competitive advantage of nations: creating and sustaining superior performance. New York: First Free Press.

Porter, M. E. (1998). Clusters and the new economics of competition. Harvard Business Review, 76(6), 77-90.

Propris De, L. D., Menghinello, S., \& Sugden, R. (2008). The internationalisation of production systems: Embeddedness, openness and governance. Entrepreneurship and Regional Development, 20(6), 493-515.

Pyke, F., \& Sengenberger, W. (1992). Industrial Districts and Local Economic Regeneration. Geneva: International Institute for Labour Affairs. 
Rugraff, E. (2010). Foreign direct investment (FDI) and supplier-oriented upgrading in the Czech motor vehicle industry. Regional Studies, 44(5), 627-638.

Sammarra, A., \& Belussi, F. (2006). Evolution and relocation in fashion-led Italian districts: Evidence from two case-studies. Entrepreneurship \& Regional Development, 18(6), 543-562.

Saxenian, A. (2000). Regional networks and innovation in Silicon Valley and Route 128. Regional Innovation, Knowledge and Global Change, Pinter, London and New York, 123-138.

Saxenian, A. (2007). Brain circulation and regional innovation: The Silicon Valley-Hsinchu-Shanghai triangle. In K.R. Polenske, The Economic Geography of Innovation (pp. 190-212). Cambridge: Cambridge University Press.

Schmitz, H. (2006). Learning and earning in global garment and footwear chains. The European Journal of Development Research, 18(4), 546-571.

Simms, C. D., \& Trott, P. (2014). Barriers to the upgrade cycle in a commodity process industry: Evidence from the UK packaging industry. $R \& D$ Management, 44(2), 152-170.

Sirén, C. A., Kohtamäki, M., \& Kuckertz, A. (2012). Exploration and exploitation strategies, profit performance, and the mediating role of strategic learning: Escaping the exploitation trap. Strategic Entrepreneurship Journal, 6(1), 18-41.

Sturgeon, T. J. (2003). What really goes on in Silicon Valley: Spatial clustering and dispersal in modular production networks. Economic Geography, 3(2), 1999-225.

Sturgeon, T., Van Biesebroeck, J., \& Gereffi, G. (2008). Value chains, networks and clusters: Reframing the global automotive industry. Journal of Economic Geography, 8(3), 297-321.

Teece, D. J. (2007). Explicating dynamic capabilities: The nature and microfoundations of (sustainable) enterprise performance. Strategic Management Journal, 28(13), 1319-1350.

Ter Wal, A. L., \& Boschma, R. (2011). Co-evolution of firms, industries and networks in space. Regional Studies, 45(7), 919-933.

Thomas, J., \& Harden, A. (2008). Methods for the thematic synthesis of qualitative research in systematic reviews. BMC Medical Research Methodology, 8(45), 1-10.

Trippl, M., Grillitsch, M., Isaksen, A., \& Sinozic, T. (2015). Perspectives on cluster evolution: Critical review and future research issues. European Planning Studies, 23(10), 2028-2044.

Tsang, E. W. (2000). Transaction cost and resource-based explanations of joint ventures: A comparison and synthesis. Organization Studies, 21(1), 215-242.

Tushman, M. L. \& Rosenkopf, L. (1992). Organizational determinants of technological change: Toward a sociology of technological evolution, In L. L. Cummings \& B. M. Staw (Eds.), Research in Organizational Behavior (14, pp. 311-347), Greenwich: JAI Press. 
Vanhaverbeke, W. (2001). Realizing new regional core competencies: Establishing a customer-oriented SME network. Entrepreneurship \& Regional Development, 13(2), 97-116.

Wall, R. S., \& Van der Knaap, G. A. (2011). Sectoral differentiation and network structure within contemporary worldwide corporate networks. Economic Geography, 87(3), 267-308.

Williamson, O. (1991). Comparative economic organization: The analysis of discrete structural alternatives. Administrative Science Quarterly, 36(2), 269-296.

Williamson, O. (1999). Strategy research: Governance and competence perspectives. Strategic Management Journal, 20(12), 1087-1108.

Winter, J. (2010). Upgrading of TNC subsidiaries: The case of the Polish automotive industry. International Journal of Automotive Technology and Management, 10(2-3), 145-160.

Zahra, S. A., Sapienza, H. J., \& Davidsson, P. (2006). Entrepreneurship and dynamic capabilities: A review, model and research agenda. Journal of Management Studies, 43(4), 917-955.

\begin{abstract}
Abstrakt
Celem artykułu jest identyfikacja i systematyzacja nurtów badawczych dotyczqcych podnoszenia pozycji regionalnych klastrów w globalnych łańcuchach wartości (GŁW). Problematyka wzrostu pozycji klastrów (cluster upgrading) należy do szerszego, i obecnie uważanego za wiodqcy, obszaru badań nad dynamikq branżowych aglomeracji. W ramach tej literatury, koncepcja wzrostu pozycji klastrów wyróżnia się koncentracjq na ich strukturalnych zmianach pod wpływem włączenia do GŁW. Na podstawie narracyjnego przegladu literatury, zidentyfikowano i scharakteryzowano dwa główne nurty badań, określone jako pozytywny i normatywny. Ponadto, opracowano model badawczy służq̨cy studiom nad uwarunkowaniami wzrostu pozycji klastrów, formułujqc pytania badawcze, które mogq stanowić punkt wyjścia do systematycznych przegladów literatury i badań empirycznych. Artykuł wnosi wkład do literatury na temat dynamiki klastrów, ze szczególnq uwagq na podnoszenie ich pozycji w GtW. Po pierwsze, prezentuje kompleksowe teoretyczne ujęcie problematyki pozycji klastrów, dokonujqc integracji rozproszonej literatury w tej dziedzinie. Po drugie, proponuje model wyznaczajqcy dalsze kierunki badań.
\end{abstract}

Słowa kluczowe: wzrost pozycji klastrów, globalne łańcuchy wartości, ewolucja klastrów, cykl życia klastra, zdolności, mechanizmy koordynacji 


\section{Biographical notes}

Marta Gancarczyk, Dr hab., Associate Professor at the Institute of Economics, Finance and Management, Jagiellonian University in Cracow, Poland. Her research, publication and consulting activities focus on entrepreneurship, firm growth, technology management and commercialization, industrial clusters and public policy for small and medium-sized enterprises. She is an Associate Editor of the international scientific journal "Journal of Entrepreneurship, Management and Innovation" and a Member of the Editorial Advisory Board of the "Journal of Organizational Change Management".

Joanna Bohatkiewicz, Ph.D. student of economics and lecturer at Jagiellonian University in Cracow, Poland, Financial Director, EKKOM Sp. z o.o. Her research interests include clusters, modularization, global value chains, crisis management, controlling and liquidity management. 